\title{
HOW TO STUDY
}




\section{How To Study: \\ A Practical Guide}

Second Edition

Francis Casey 
(C) Text: Francis Casey 1985, 1993

(C) Illustrations: Jim Whittaker 1985

All rights reserved. No reproduction, copy or transmission of this publication may be made without written permission.

No paragraph of this publication may be reproduced, copied or transmitted save with written permission or in accordance with the provisions of the Copyright, Designs and Patents Act 1988, or under the terms of any licence permitting limited copying issued by the Copyright Licensing Agency, 90 Tottenham Court Road, London W1P 9HE.

Any person who does any unauthorised act in relation to this publication may be liable to criminal prosecution and civil claims for damages.

First edition 1985

Reprinted 1986, 1988, 1989, 1990, 1991, 1992

Second edition 1993

Published by

THE MACMILLAN PRESS LTD

Houndmills, Basingstoke, Hampshire RG21 2XS

and London

Companies and representatives

throughout the world

ISBN 978-0-333-59788-0

ISBN 978-1-349-13279-9 (eBook)

DOI 10.1007/978-1-349-13279-9

A catalogue record for this book is available from the British Library. 
To

my mother

and to the memory of

my father 


\section{Contents}

Acknowledgements

viii

Preface

1 First principles 1

2 Early practicalities $\quad 8$

3 How to plan your study 12

4 Reading 20

5 Using libraries 28

6 Notes 38

7 Essay writing 48

8 Projects 67

9 Other formats 78

Diagrams

Graphs

Tables

Writing up experiments

10 Understanding, memory and recall 90

11 Examinations 95

$\begin{array}{lll}\text { Appendix } 1 & \text { Leisure reading list } & 109\end{array}$

Appendix 2 Reference books 113

Appendix 3 Newspapers and periodicals 117

Appendix 4 A student's glossary $\quad 120$

$\begin{array}{ll}\text { Index } & 132\end{array}$ 


\section{Acknowledgements}

The author and publishers wish to thank the following who have kindly given permission for the use of copyright material:

The Controller, HMSO, for an extract from the Annual Abstract of Statistics.

Pitman Publishing Ltd, London, for an extract from Plant and Animal Biology by Vines and Rees. 


\section{Preface}

It is not enough to study hard; you must learn how to study efficiently.

The aim of this book is to teach you the essentially simple techniques of personal organisation and study method, whether you are in the senior years of secondary school, at college or university, studying in adult education or following a correspondence course at home.

Students frequently under-achieve because of negative attitudes, poor planning and unawareness of basic approaches to the use of books, note making, essay writing and revision. How To Study offers detailed guidance in all of these areas, and many more.

The book is practical because it is understood that you do not have the time to pore over a lengthy volume, to concern yourself with theory or to work through a series of exercises related to the text. What you will find within is a wealth of commonsense advice - concisely and simply expressed - which you can begin to follow without delay.

My intention is that this book should represent a helpful and uncomplicated response to a very real need. For enabling me to identify the need, I am grateful to all of my students and pupils, past and present. For helping me to prepare this response, I am especially indebted to Andrew Berriman, for his committed and reliable assistance: to Jill Pinn, Andrew Manley and David Linsell, for their valuable contributions: to many other colleagues - too numerous to mention by name - for the wisdom and professional expertise on which I have been able to draw: to my wife, Gill, and children, Ben, Eleanor, Matthew and Jonathan, for their encouragement and unfailing support. 